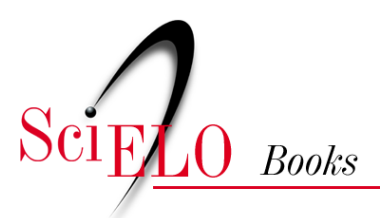

\title{
Considerações finais: no caminho, as cidades novas
}

\author{
Ricardo Trevisan
}

\section{SciELO Books / SciELO Livros / SciELO Libros}

TREVISA, R. Considerações finais: no caminho, as cidades novas. In: Cidades novas [online]. Brasília: Editora UnB, 2020, pp. 259-266. Pesquisa, inovação \& ousadia series. ISBN: 978-65-5846-158-6. https://doi.org/10.7476/9786558461586.0012.

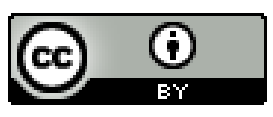

All the contents of this work, except where otherwise noted, is licensed under a $\underline{\text { Creative }}$ Commons Attribution 4.0 International license.

Todo o conteúdo deste trabalho, exceto quando houver ressalva, é publicado sob a licença Creative Commons Atribição 4.0.

Todo el contenido de esta obra, excepto donde se indique lo contrario, está bajo licencia de la licencia Creative Commons Reconocimento 4.0. 


\section{Considerações finais: no caminho, as cidades novas}

Ao fim desta jornada teórico-conceitual pelo universo das CNs, convido a todos a desembarcarem. Infelizmente peço isso não pela falta de exemplares a serem visitados, mas pela consciência de ter alcançado até aqui um conhecimento e um repertório instrumental suficientes para a realização de estudos futuros.

Se mais tempo tivéssemos, continuaríamos por outras CNs, no exterior e no Brasil. Poderíamos ir à Índia, visitar a CN de Auroville - conhecida também por Cidade do Amanhecer -, uma proposta utópica, projetada como uma espiral e respeitando os princípios do Ioga. Foi materializada em 1968 para ser um "local universal de educação e amizade entre os povos” (QUERRIEN; LASSAVE, 2005, p. 3, tradução nossa). ${ }^{1}$

Poderíamos ir à Holanda, descobrir a contemporânea Almere, uma cidade-satélite a leste de Amsterdã, fundada pelo governo holandês em 1971, a partir de uma política de urbanização controlada do território iniciada em 1918. Desse plano, 18 vilas e três CNs (Emmeloord, Lelystad e Almere) foram implantadas sobre terras conquistadas em áreas antes alagadas (flevoland ou pôlderes). Atualmente com 180 mil habitantes, Almere é destino obrigatório para estudiosos da arquitetura contemporânea, possuindo projetos de profissionais em destaque, como Rem Koolhaas e os escritórios MVRDV e SANAA.

Poderíamos ir à Inglaterra, aos Estados Unidos da América ou aos Emirados Árabes Unidos verificar as propostas de cidades embasadas por discursos de sustentabilidade. Veríamos Sir Peter Hall defender a sua Sustainable Social City 2000 na Inglaterra, uma cidade baseada nos princípios de cidade-jardim e caracterizada

1 “[...] lieu universel d'éducation et d'amitié entre les peuples.” 
por: transporte público, usos diversificados do solo, natureza próxima, casas com qualidade, economia balanceada, empregos para todos, serviços locais, acesso global etc. (HALL, 1996). Veríamos o escritor norte-americano Joel Garreau propor, em seu livro Edge City - Life on the New Frontier, de 1991, uma solução urbanística dos tempos atuais: as edge cities ou cidades-limites implantadas para além das zonas suburbanas, ocupando áreas gigantescas, do tamanho de cidades de médio porte, e embasadas por discursos ecologicamente corretos. Veríamos, ainda, o devaneio de arquitetos em Dubai, nos Emirados Árabes Unidos, ao imaginarem a cidade ecológica e autossustentável de Ziggurat, uma CN em megaestrutura piramidal, com instalação de turbinas eólicas e painéis solares para produção de energia, além de transporte feito por uma rede de monotrilhos e elevadores ligados por todo o prédio, sem a necessidade de automóveis.

Poderíamos ir ao Japão, relaxar em Tsukuda, a nordeste de Tóquio. Fundada no ano 2000, a CN japonesa nasceu com um novo conceito para os padrões de vida urbana: a slow life (vida pacata), contrapondo-se ao estresse e à agitação das grandes metrópoles. Novamente, a CN aparece como solução aos males da vida contemporânea.

Poderíamos ir a países africanos em conflitos, atentar para o uso das CNs como solução para abrigar milhares de refugiados de guerra. Criadas na urgência como um dispositivo de proteção para garantir a seguridade física, alimentar e sanitária de todos aqueles fugitivos de guerras, os campos de refugiados aglomeram dezenas de milhares de habitantes por períodos em geral muito mais longos que aquele de urgência. Edificados no começo como um autêntico deserto ou como um não lugar, os campos podem se tornar cidades. CNs surgidas a partir de um sistema de sobrevivência, como um "estabelecimento relativamente importante, denso e permanente de indivíduos socialmente heterogêneos, promotor de oportunidades de encontros, de trocas e de reelaborações identitárias entre todos seus habitantes” (AGIER, 2001, p. 130, tradução nossa). ${ }^{2}$

“[...] établissement relativement important, dense et permanent d'individus socialement hétérogènes, promoteur d'opportunités de rencontres, d'échanges et de ré-identifications identitaires entre tous ses habitants.” 
Considerações finais

Figura 18: Aureville

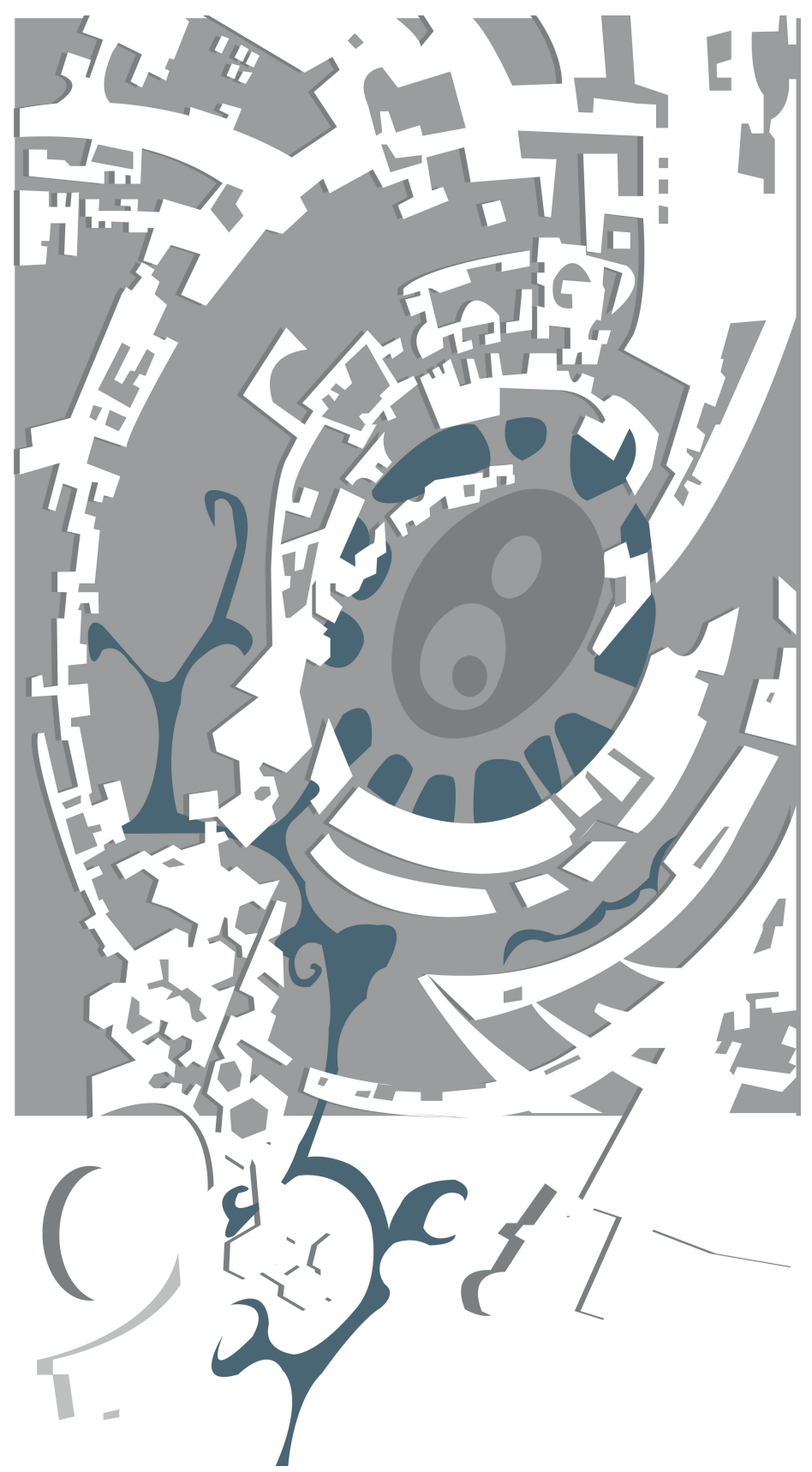


Poderíamos ir a um litoral, aguardar a elevação do nível dos oceanos e imaginar as CNs que surgirão em consequência das catástrofes naturais. Grandes estruturas, como a Lilypad do arquiteto belga Vincent Callebaut, uma cidade flutuante sobre o mar identificada como o novo espaço urbano da sociedade do futuro (ROUAT, 1996).

Poderíamos até ir ao mundo virtual, discutir as possibilidades de haver uma CN virtual, originária dos avanços tecnológicos, já profetizada por alguns estudiosos, como fez William J. Mitchell em E-Topia: urban-life - but not as we know it, de 1999.

Poderíamos, mesmo, ficar no Brasil e aguardar as futuras capitais que irão surgir com os novos estados e territórios previstos em projetos que tramitam, atualmente, no Congresso Nacional (previsão: 43 estados, 3 territórios e distrito federal). Campos férteis para a criação de CNs administrativas, essas ações já despertam o interesse de empreendedores - como ocorre na região de Carajás, no Pará -, que veem na compra de terras e no planejamento de futuras obras atividades altamente lucrativas.

Poderíamos, mas essas e outras possibilidades ficarão para uma próxima jornada.

\section{Afinal, o que são cidades novas?}

Ao encerrar este livro, recupero as principais ideias nele abordadas com intuito de certificar ao leitor que as respostas a tal questionamento inicial foram, por instante, delimitadas.

Certo da classificação das CNs como um tipo urbanístico, pude observar o contexto no qual elas se inserem, cercadas por aspirações utópicas e por realizações concretas. Cidades sonhadas, imaginadas, teorizadas e criadas a fim de servir aos ideais e às necessidades de um determinado período.

Em seguida, identifiquei as várias definições empregadas para um mesmo objeto, distintas conforme o momento histórico, os aspectos físico-sociais envolvidos e o interesse particular de seus pesquisadores. Definições, por vezes, pouco contextualizadas à nossa realidade, mas propícias à elaboração de um conceito funcional. Conceito este representado pelo DNA das CNs, no qual estruturei os seis 
elementos definidores desse tipo urbanístico: desejo, função, lugar, profissional, projeto e tempo, conectados à linha temporal da história.

De antemão, busquei relacionar en passant a origem das CNs a um conjunto de fatores mais abrangentes que os meros seis segmentos, ou seja, procurei constatar que elas nascem a partir de um contexto político-econômico-sócio-cultural propício. Neste livro, isso foi evidenciado nas introduções a cada capítulo, pela narrativa histórica do surgimento de alguns exemplares no Brasil. Pequenas histórias que expõem, de um lado, as conjunturas que favoreceram a criação dessas CNs e, de outro, as características que permitiram trabalhar determinado atributo.

Contudo, não basta apenas ter um cenário propício se não há, no processo, o agente starter. Assim, creditei ao empreendedor - o genitor das CNs - um papel fundamental na definição conceitual desse tipo urbanístico. O desejo, a vontade de criar uma CN parte, especificamente, da figura do empreendedor ou de um grupo deles, portadores de capital público e/ou privado. É ele quem assume o desejo, a intenção, o querer criar uma nova cidade; é ele quem promove as ações; é ele o responsável por assegurar capital para efetivar o empreendimento.

Junto ao desejo está a necessidade, dois atributos inseparáveis que surgem simultaneamente na história de cada CN. Necessidade traduzida pela função dominante, a função em destaque nos primeiros anos de vida da cidade recém-criada. Atributo no qual destaquei a multiplicidade, isto é, a variedade de funções dominantes existentes (12 até agora diagnosticadas). Atributo que marca no mapa genético das CNs a causa para a qual foram geradas.

Do desejo e da necessidade, passei ao ambiente natural, à implantação das CNs e suas particularidades. Nesse sentido, o lugar aparece como um elemento possuidor de dois aspectos importantes. O primeiro refere-se ao sítio e suas condicionantes geográficas, aquelas que irão favorecer a implantação da urbe, diretamente relacionados à atenção do(s) empreendedor(es) - estudo minucioso do local - e à função dominante - qualidades inerentes ao local. O segundo refere-se ao sítio como condicionante projetiva, em que o meio ambiente pode ou não ser considerado ao se 
desenhar o traçado e o tecido da $\mathrm{CN}$ - parâmetro de análise do projeto implantado. Sob e sobre o lugar selecionado, dados importantes se apresentam para uma maior compreensão das CNs.

A partir dessa trilogia preliminar, seguiram-se os atributos que caracterizam a materialização das CNs: o profissional e o projeto. O profissional, ou melhor, o urbanista - detentor de um conhecimento obtido em diversas áreas -, solitário ou auxiliado por uma equipe, é o responsável por tornar o desejo, o sonho, a motivação em realidade espacial, com menor ou maior grau de detalhamento, consoante o seu arcabouço técnico. Ao caracterizar a personagem, distingui-a de outra, o empreendedor, que não detém um saber-fazer cidades. Dois agentes separados neste livro, cada qual com seu papel específico na tarefa de construir CNs.

Do planejamento ao projeto, surgiram as CNs. Cidades planejadas ao serem, durante um período gestacional, alvo de uma preparação - antecipar-se ao que ainda não é, mas que tem a possibilidade de ser. Trata-se da elaboração de planos e ações visando à projetação unitária do espaço físico urbano. Projetos por mim classificados (CNs fechadas ou abertas; CNs em 2D ou em 3D) e exemplificados. O atributo mais detalhado neste livro em função do repertório profissional pessoal e como contribuição aos estudos na área da morfologia urbana.

Por fim, expus o tempo das CNs, o tempo específico a cada uma delas, o "tempo de curta duração”. Um tempo que separei em ciclos: gestacional, nascimento e desenvolvimento preliminar; período que se estende até a $\mathrm{CN}$ atingir sua maioridade e se tornar uma cidade. Tempo que percorre os demais atributos durante a precoce história de origem de cada CN. Um tempo intra-DNA, distinto daquele mais amplo e abrangente, conectado à história da humanidade.

O tempo histórico, ou “tempo de longa duração”, representado nesta obra pelos infindáveis exemplares visionados e construídos desde a Antiguidade até hoje, permitiu visualizar o percurso das CNs ao longo dos séculos. Um percurso marcado por mudanças nos aspectos político-econômico-sócio-culturais, pelos avanços tecnológicos, pelas diferentes abordagens de conhecimento, pelos adventos de novas teorias urbanas etc. 
Transformações que limitam cada CN a um período histórico diferente. Recortes temporais que contribuem para uma análise das CNs conforme os profissionais recorrentes, as variações formais no desenho urbano ou mesmo para verificar o uso de uma só função dominante em épocas distintas. Um universo de fatores que gera CNs específicas. Uma amplitude temporal que garante a existência de uma história das CNs.

Assim, concluo que a estrutura científica aqui elaborada, pessoal e efêmera, para definir o que são cidades novas deve ser pautada em seis atributos indissociáveis: o desejo em criar as CNs, a função para qual foram inicialmente idealizadas, a escolha de um sítio específico para sua implantação, o envolvimento de um profissional e o seu saber-fazer cidades, a presença de um projeto urbanístico e um tempo de criação e desenvolvimento específicos. Ao serem reunidos, tais atributos devem ser contextualizados no tempo histórico. Uma definição que permitirá aos interessados identificar as CNs - verificar sua boa ou má formação genética - e manipulá-las cientificamente segundo critérios e enfoques pré-estabelecidos, seja a partir de um ou de mais atributos inerentes ao seu DNA.

Estudiosos e pesquisadores poderão focar suas atenções sobre os empreendedores, do setor privado ou do poder público, que desejaram criar cidades visando a suprir uma vontade. Poderão se deter na multiplicidade de funções dominantes para as quais essas cidades foram empreendidas. Poderão destacar a importância da escolha de sítios estratégicos no aparecimento dessas cidades. Poderão revelar a participação da figura do urbanista (arquiteto, engenheiro civil, militar, agrônomo, agrimensor, equipes multidisciplinares etc.) na sua concepção - profissionais por vezes esquecidos ou desconhecidos dos estudos urbanísticos. Poderão ampliar o campo de pesquisa sobre a morfologia urbana, trazendo à tona os projetos, seu traçado e seu tecido. Poderão, por fim, atentar para o planejamento, a fundação e o desenvolvimento dessas cidades, tendo o tempo próprio ou o tempo histórico como foco de interesse.

Peças (atributos) de um puzzle que permite a qualquer jogador interessado jogar e definir o que é e o que não é $\mathrm{CN}$. Um jogo que não pretende ditar as únicas regras sobre o tabuleiro, mas que se mostra pioneiro ao inaugurar tal passatempo. 
Ao parafrasear Léfèbvre (1969) - No caminho, as cidades novas -, lembro que essa viagem é apenas o começo. Dessa empreitada preliminar, uma viagem sem horizontes se abre à frente deste pesquisador: um caminho a ser percorrido a fim de desvendar, aprofundar e revelar conhecimento sobre o conjunto das CNs.

Particularmente, atualmente realizo uma pesquisa mais detalhada sobre os mais de 260 exemplares brasileiros já identificados. Nesse sentido, busco atualizar a listagem com a descoberta de novos exemplares e direciono a pesquisa para uma breve avaliação caso a caso, no intuito de montar, como fizeram Lagrange e Demur (2005), uma ficha cadastral com os dados biográficos e iconográficos de cada CN. Trata-se, pois, da construção de um “Atlas de cidades novas no Brasil Republicano”, ${ }^{3}$ referência para consultas, pesquisas, análises e estudos urbanísticos (TREVISAN, 2018). Um trabalho que demandará tempo, mão de obra e dedicação por toda uma carreira, auxiliado pela colaboração de outros pesquisadores, docentes e discentes interessados.

Essas possibilidades foram aqui brevemente esboçadas mediante as dezenas de exemplares articulados ao longo da construção teórica. CNs nascidas de uma vontade, do desejo humano, caracterizadas por uma versatilidade para atender às mais diferentes funções, por uma adaptabilidade de se adequar aos sítios mais adversos, por um desenho sobre o solo ou sobre a prancheta, por um campo de ideias espaciais mesclados na cronologia de um tempo preciso.

Um quadro, que, ao ser finalizado, se revela rico e diversificado, ao mesmo tempo que único. Um mosaico colorido pelas diferentes personagens que o compõem; uma justaposição que deixa à retina a tarefa de reconstruir o tom e a imagem desejados pelo pintor, combinando as diversas impressões registradas. Uma imagem única, como fizeram os egípcios ao sintetizar a cidade e seus elementos. Uma pintura síntese exposta para definir o que são cidades novas. Um livro que deixa ao leitor a tarefa de continuar a pintar.

3 Pesquisa “Atlas de cidades novas no Brasil Republicano", sob apoio financeiro do CNPq (Bolsa de produtividade), desenvolvida no Laboratório de Estudos da Urbe (Labeurbe) da Faculdade de Arquitetura e Urbanismo da Universidade de Brasília e atrelada ao projeto "Cronologia do Pensamento Urbanístico” (http://www.cronologiadourbanismo.ufba.br/). 